\title{
Assessment of Distress Among Chemotherapy Patients: A Comparative Study of Gender
}

\author{
Cristiane Decat Bergerot ${ }^{1}$ \\ Tereza Cristina Cavalcanti Ferreira de Araujo \\ Bartholomeu Tôrres Tróccoli \\ Universidade de Brasília, Brasília-DF, Brazil
}

\begin{abstract}
The aim of this study was to evaluate, analyze and understand distress levels experienced during chemotherapy treatment, comparing men and women. The sample was composed of 328 patients recruited from an Oncology center. Data collection included the application of the Distress Thermometer at three stages of chemotherapy: beginning, middle and end. Incidence of distress decreased in both genders over the course of assessments. Comparatively, the incidence was higher among women, who also reported the highest number of problems in the practical, family, emotional, spiritual and physical domains. The results corroborate the international literature on the subject. Clinical interest of systematic assessment of distress was confirmed to develop routines of therapeutic monitoring adapted to the specific needs of cancer patients.
\end{abstract}

Keywords: cancer patient, gender, evaluation, psycho-oncology

\section{Avaliação de Distress Entre Pacientes em Quimioterapia: Um Estudo Comparativo de Gênero}

\begin{abstract}
Resumo: A presente investigação teve por objetivo avaliar, analisar e compreender os níveis de distress vivenciados durante o tratamento quimioterápico, comparando-se homens e mulheres. A amostra foi constituída de 328 pacientes, recrutados em um centro especializado em Oncologia. A coleta de dados envolveu a aplicação do Termômetro de Distress em três etapas da quimioterapia: início, meio e fim. Constatou-se queda dos escores de distress, em ambos os gêneros, no decorrer das avaliações. Comparativamente, a incidência foi maior entre as mulheres, as quais também reportaram maior número de problemas, nos domínios prático, familiar, emocional, espiritual e físico. Os resultados obtidos corroboram a literatura internacional. Comprovou-se o interesse clínico da avaliação sistemática do distress para estruturação de rotinas de acompanhamento terapêutico ajustadas às necessidades específicas de pacientes com câncer.
\end{abstract}

Palavras-chave: paciente de câncer, gênero, avaliação, psico-oncologia

\section{Evaluación de Distress Entre Pacientes en Quimioterapia: Un Estudio Comparativo de Género}

\begin{abstract}
Resumen: El objetivo de esta investigación fue evaluar, analizar y comprender los niveles de distress experimentados durante el tratamiento con quimioterapia, comparando hombres y mujeres. La muestra fue constituida por 328 pacientes reclutados en un centro especializado en oncología. Para recopilar los datos fue aplicado el Termómetro de Distress en tres etapas de la quimioterapia: principio, medio y final. La incidencia de distress en ambos sexos cayó en el curso de la evaluación. En comparación, la incidencia fue mayor entre las mujeres, que también reportaron el mayor número de problemas en los campos práctico, familiar, emocional, espiritual y físico. Los resultados obtenidos corroboran la literatura internacional. Se comprobó la importancia clínica de la evaluación sistemática del distress para estructurar las rutinas de acompañamiento terapéutico adaptadas a las necesidades específicas de los pacientes con cáncer.
\end{abstract}

Palabras clave: paciente de cáncer, género, evaluación, psico-oncología

Differences between men and women are the focus of interest in various fields of knowledge. So far, few topics have raised so many questions and so much debate as the distinction between genders. Various studies have been conducted to clarify similarities and peculiarities of each (Boquiren, Esplen, Wong, Toner, \& Warner, 2013; Fávero, 2010; Poeschl, Múrias, \& Ribeiro, 2003; Rogers \& Rogers, 2001; Steensma, Kreukels, de Vries, \& Cohen-Kettenis, 2013; Toner et al., 2012).

In short, it is possible to organize beliefs concerning the differences between men and women into two general axes: (a) instrumentality - masculinity is characterized by focusing on

\footnotetext{
${ }^{1}$ Correspondence address:

Cristiane Decat Bergerot. SMH/N Od. 02 Bl. A, Ed. de Clínicas, $12^{\circ}$ Andar. CEP 70710-904. Brasília-DF, Brazil. E-mail: crisdecat@yahoo.com.br
}

objectives, emotional inhibition, establishment of relationships useful to achieving goals, the ability to perform tasks and act independently; and (b) expressiveness and 'commonality' femininity is revealed by the expression of emotions and feelings, a concern with family needs, flexibility, valorization of others and an ability to care of others (López-Sáez, Morales, \& Lisbona, 2008; Poeschl et al., 2003; Silva, Mendonça, \& Zanini, 2010).

Gender stereotypes may change among different societies. Additionally, ideologies constructed around masculinity and femininity focus on conceptions concerning emotions and body, influencing individuals' self-esteem and self-care (Fávero, 2010). In regard to health, it is essential to understand and reflect upon gender roles given the need to provide therapeutic guidance and develop programs and public policies for each health specialty. 


\section{Health and Disease: A Matter of Gender}

In recent years, there has been growing clinical and scientific interest in regard to the relationship between gender and health and disease. Differences in health conditions, use of services, and adjustment to chronic diseases stand out among the subjects addressed (Snooks, 2009). Various studies suggest that the need for care is a predominantly female demand, contrary to the masculine standard - women seek health services more frequently than men and are more active during consultations, asking more questions and showing greater interest. As a consequence, health professionals would spend more time attending female patients. Apparently, they live longer, and report more morbidities and psychological problems (Bernardes, Silva, Carvalho, Costa, \& Pereira, 2013; Gomes, 2003; Macintyre, Ford, \& Hunt, 1999; Mast, Klöckner, \& Hall, 2010; Verbrugge, 1989).

There is a cultural belief that the male body does not require care since it is a synonymous with power, performance and invulnerability, impervious to physical or psychological disorders. For some authors, the refusal to practice self-care and adopt preventive health measures suggest the discomfort men experience in situations associated with submission and dependence on someone with more knowledge, such as a physician or other health worker. The literature highlights that men tend to adopt problem-focused coping strategies, while women emphasize emotion-focused strategies (Gomes, 2003; Good \& Sherrod, 2001; Verbrugge, 1989).

In Brazil, studies also reveal that women more frequently seek health services to implement preventive measures. This evidence may explain the larger number of men hospitalized for severe conditions, as well as the fact they do not live as long as women. Brazilian women are more likely to become sick due to stress and depressive symptoms, while men are more prone to professional stress and the abuse of substances such as alcohol and tobacco (Bernardes et al., 2013; Figueiredo, 2005; Gomes, Nascimento \& Araújo, 2007; Pinheiro, Viacava, Travassos, \& Brito, 2002; Rabasquinho \& Pereira, 2007). Costa-Júnior and Maia (2009) reported that a male sample only sought medical care when symptoms resulted in physical and/or occupational restrictions or when the limitations imposed by the disease anticipated more severe consequences.

Among current common illnesses, diverse types of cancer and their repercussions on the personal and collective spheres are highlighted. In this sense, both clinical practice and scientific studies warn of the need to increase our understanding of certain variables that are clearly gender-related variables.

\section{Gender and Cancer}

The ongoing development of early detection techniques, as well as diagnostic procedures and treatments, has progressively reduced the fear, fatalism, and the stigma associated with cancer. The current survival rate for breast cancer patients in the initial stages is $98 \%$, while survival may reach $88 \%$ in more advanced clinical states. Despite these achievements at the technical level, there is still a need to deepen knowledge at the psychosocial level (American Cancer Society, 2006; Hagedoorn, Sanderman, Bolks, Tuinstra, \& Coyne, 2008; Salander \& Hamberg, 2005).

According to Loscalzo, Kim and Clark (2010), gender is a primary variable that has been seldom explored in Oncology. These authors consider it essential to clarify the inclinations of men and women to deal with distress, their possibilities for social support and repercussions of the disease and treatment on quality of life. It is worth clarifying that distress in Oncology is defined as an unpleasant and multifactor emotional experience that may interfere in one's ability to effectively deal with the diagnosis and treatment of cancer (Holland et al., 2013).

Data from scientific studies show similar conditions between women with cancer and women with other chronic diseases. Apparently, female patients are more willing to share their anxieties and fears; asking for help does not decrease their self-esteem. On the other hand, the responses of men experiencing similar situations mainly include 'fight or flight'. When facing uncontrollable stressors, men seek internal resources to solve the problem. As opposed to women, men may experience low self-esteem when manifesting their vulnerability and tend to minimize their suffering and physical symptoms. They prefer to receive scientific information from the health staff instead of emotional support (Greimel, Padilla, \& Grant, 1998; Hagedoorn et al., 2008; Loscalzo et al., 2010; McCaughan, Prue, Parahoo, Mcllfatrick, \& McKenna, 2012).

The literature is inconsistent in regard to differences between genders when it comes to distress, which is established by the American Cancer Society as the 'sixth vital sign'; that is, it is a key indicator for the monitoring of patients' clinical conditions (Decat, Araujo, \& Stiles, 2011; Holland \& Bultz, 2007). Clark, Loscalzo, Trask, Zabora and Philip (2010) noted that men with pancreatic cancer expressed more distress when compared to women. In contrast, various authors (Admiraal, Reyners, \& HoeskstraWeebers, 2013; Akechi et al., 1998; Dunn et al., 2013; GieseDavis et al., 2012; Hamama-Raz, 2012) reported higher levels of distress among women than men. Fife, Kennedy and Robinson (1994) also reported higher scores for women, though the same female sample established better coping strategies in the sexual, social and professional domains. Hagedoorn, Buunk, Kuijer, Wobbes and Sanderman (2000) reported a greater incidence of distress and lower quality of life in the female population they addressed.

A meta-analysis of studies published between 1980 and 2005 verified the relationship between distress and gender among couples in which one of them was affected by cancer. The sick women reported more distress than their partners and studies addressing male patients reported distress was higher among the female partners. No statistical significance was found in samples of couples in which one of the partners was diagnosed with cancer without identifying gender (Hagedoorn et al., 2008).

In a comparative study between prostate cancer and breast cancer patients, Kiss and Meryn (2001) detected differences in terms of physical impact, sexual activity, quality of life, and 
coping, as well as the response of their spouses. The authors observed that between $20 \%$ and $30 \%$ of women manifested anxiety and depression six months after their diagnosis. In contrast, men expressed more specific symptomatology: intolerance, impulsivity, alcohol consumption, and aggressive behavior. For these authors, the attempt of patients with prostate cancer to ignore the diagnosis was related to a limited perception of the need for help, fear of stigmatization, the requirements of a professional occupation and a desire to escape the disease.

Confirming these perspectives, Salander and Hamberg (2005) perceived that women and men respond differently to the diagnosis. Women developed long and detailed narratives, and their reports were personal and emotional, with an emphasis on social support, while men favored impersonal reports and only $26 \%$ mentioned feelings. According to Nicholas (2000), the worse psychosocial adaptation of men undergoing oncological treatment is due to their less adaptive responses, such as not seeking social support.

In summary, the literature indicates there are gender distinctions not only in biological processes, but also in relation to life conditions, environmental experiences, risk behavior, and response to stressors (Baider \& Bengel, 2001; Rezende et al., 2010). Such evidence needs to be better known because the prevalence of cancer in the world population has not receded.
On the contrary, rates are growing and cancer is a major cause of mortality worldwide. Brazilian estimates of new cases projected for 2012 are of 257,030 new female patients and 260,640 new male patients (Ministério da Saúde, 2011).

Therefore, acknowledging the importance of the relationship between gender and cancer is essential. There is a lack of longitudinal studies addressing this topic in Brazil. For this reason, this study's objective was to assess, analyze and understand levels of distress between men and women at the beginning, in the middle and at the end of chemotherapy.

\section{Method}

\section{Participants}

A total of $118(36 \%)$ men and $210(64 \%)$ women composed the sample and were selected according to the following criteria: established diagnosis of cancer; minimum age of 18 years old and maximum age of 86 years; and being able to answer the distress assessment instrument. The mean age was 54.7 years old (men: 55.2; $S D=18$; women: 54.5; $S D=14.6$ ). Most were married and $43.6 \%$ reported having a bachelor's degree. Gastrointestinal and hematological cancer predominated among men, while breast cancer and gastrointestinal cancer were the most frequent diagnoses in the subsample of women. Table 1 presents the participants' socio-demographic characterization.

Table 1

Socio-Demographic Characteristics of Patients According to Gender $(N=328)$

\begin{tabular}{|c|c|c|c|c|c|c|}
\hline \multirow{2}{*}{ Characteristics } & \multicolumn{2}{|c|}{ Male } & \multicolumn{2}{|c|}{ Female } & \multicolumn{2}{|c|}{ Total } \\
\hline & $n=118$ & $\%$ & $n=210$ & $\%$ & $N=328$ & $\%$ \\
\hline \multicolumn{7}{|l|}{ Marital status } \\
\hline Single & 18 & 15.2 & 27 & 12.9 & 45 & 13.7 \\
\hline Married & 87 & 73.7 & 116 & 55.2 & 203 & 61.9 \\
\hline Divorced & 8 & 6.8 & 35 & 16.7 & 43 & 13.1 \\
\hline Widowed & 5 & 4.3 & 32 & 15.2 & 37 & 11.3 \\
\hline \multicolumn{7}{|l|}{ Education } \\
\hline Illiterate & 5 & 4.3 & 4 & 1.9 & 9 & 2.7 \\
\hline Elementary & 12 & 10.2 & 39 & 18.6 & 51 & 15.6 \\
\hline High School & 37 & 31.4 & 43 & 20.5 & 80 & 24.4 \\
\hline Undergraduate & 50 & 42.4 & 93 & 44.4 & 143 & 43.6 \\
\hline Graduate studies & 14 & 11.7 & 31 & 14.6 & 45 & 13.7 \\
\hline \multicolumn{7}{|l|}{ Types of cancer } \\
\hline Breast & 0 & 0 & 78 & 37.2 & 78 & 23.8 \\
\hline Gastrointestinal & 46 & 38.9 & 46 & 21.9 & 92 & 28 \\
\hline Hematologic & 37 & 31.4 & 37 & 17.6 & 74 & 22.6 \\
\hline Gynecologic & - & - & 29 & 13.8 & 29 & 8.8 \\
\hline Genitourinary & 10 & 8.5 & 4 & 1.9 & 14 & 4.3 \\
\hline Head and Neck & 9 & 7.6 & 0 & 0 & 9 & 2.7 \\
\hline Lungs & 8 & 6.8 & 10 & 4.8 & 18 & 5.5 \\
\hline Sarcoma & 6 & 5.1 & 4 & 1.9 & 10 & 3.1 \\
\hline Melanoma & 2 & 1.7 & 2 & 0.9 & 4 & 1.2 \\
\hline \multicolumn{7}{|l|}{ Stage of Cancer } \\
\hline I & 7 & 5.9 & 26 & 12.4 & 33 & 10.1 \\
\hline II & 16 & 13.6 & 46 & 21.9 & 62 & 18.9 \\
\hline III & 27 & 22.9 & 61 & 29 & 88 & 26.8 \\
\hline IV & 53 & 44.9 & 57 & 27.1 & 110 & 33.5 \\
\hline Missing data & 15 & 12.7 & 20 & 9.5 & 35 & 10.7 \\
\hline
\end{tabular}


There was variation in the sample size throughout the assessment stages: beginning $(N=328)$, middle $(N=285)$, and end $(N=261)$ of treatment for various reasons, such as: death $(22 \%$ men and $13.8 \%$ women); change of the cancer treatment facility $(2.5 \%$ men and $0.9 \%$ women $)$; return to hometown (1.7\% men and $1.4 \%$ women); and abandonment of treatment $(0.8 \%$ men and $0.4 \%$ women).

\section{Instruments}

A socio-demographic questionnaire and the Distress Thermometer (DT), proposed by the National Comprehensive Cancer Network (2007), adapted and validated by Decat, Laros and Araujo (2009), were used. DT presents an illustration of a thermometer that assesses the level of distress on an 11-point scale, 0 (no distress) to 10 (extreme distress), with a score equal or higher than 4 that indicates distress (sensitivity of $82 \%$ and specificity of $98 \%$ ). DT includes a List of Problems (LP) with 35 items to identify potential causes of distress, which is subdivided into practical, family, emotional, spiritual and physical domains (Decat et al., 2011).

\section{Procedure}

Data collection. This was performed in a private treatment center, specializing in the care of cancer patients - the Brasilia Cancer Center (CETTRO) - from September 2008 to February 2012. All the patients initiating chemotherapy in this center were contacted by the psychologist and invited to participate in the study. Those who consented signed free and informed consent forms and answered the socio-demographic questionnaire and the DT on the first day of their chemotherapy. The DT was reapplied in similar conditions in the subsequent stages of treatment. The parameters that determined the assessment stages were established by the assistant physician according to the chemotherapy protocol prescribed for each case, having an average interval of two and a half months. At the end of each assessment, analysis and clinical discussion took place with the assistant physicians to establish therapeutic measures adjusted for each patient.

Data analysis. The statistical program SPSS 17.0 for Mac was used in all the analyses. Descriptive analysis was employed for the participants' socio-demographic characterizations, as well as the frequency of problems reported in the LP. Logistic regression was employed to determine the discriminatory/predictive power of the problems reported according to gender. For that, we adopted the Stepwise method for each stage of assessment. The ANOVA repeated measures test was used to identify potential relationships between the means of levels of distress and gender in the three stages of treatment. This analysis was performed only with the data provided by the patients who participated in all the assessment stages (86 men and 175 women).

\section{Ethical Considerations}

As specified by Resolution 196/96, National Council of Health, the project was submitted to and approved by the Institutional Review Board at Faculdade de Ciências da Saúde, Universidade de Brasília (UnB) with protocol No. 056/2007.

\section{Results}

Table 2 presents the main problems reported by men and women over the course of treatment. Among the practical problems reported at the beginning of treatment, 'insurance/financial' was the most frequent, followed by 'work', reported by men, and 'housing', reported by women. Problems related to 'work' were the third most frequently item reported by women. Both groups reported that 'dealing with children' was the main family problem. Among emotional issues, the participants reported 'worry', 'nervousness' (men) and 'sadness' (women). The physical problems most frequently reported by men were 'sleep', 'pain', 'fatigue', and 'eating'. In turn, women reported 'memory/concentration', 'sleep', 'appearance' and 'fatigue'.

At the second stage of evaluation, similar results were verified, though women reported 'appearance' and described difficulties concerning 'housing' and 'work'. Spiritual problems were also more frequently reported by women. At the end of the chemotherapy, the items most frequently reported by both men and women were 'insurance/financial', 'work', 'dealing with children' and 'worry'.

Table 3 presents the regression coefficients, probability (Odds Ratio) and a confidence interval of $95 \%$ for the probability of variables able to significantly discriminate between men and women. These results show that, in general, women acknowledge more problems than men in the three stages of assessment, with the exception of 'changes in urination' (at the beginning of the treatment); 'work', 'changes in urination', 'eating', 'pain' (middle of treatment); and 'work' and 'eating' (at the end of the treatment).

The results of the ANOVA repeated measures indicate problems of homogeneity of variance and the normality of distributions in the conditions of the research. Consequently, a level of significance of 0.025 was chosen to compensate for the increase in the level of Type I errors due to the non-normality or heterogeneity of variance. A significant main effect was found for the variable gender $F(1.259)=914.31 ; p<.001$; eta squared $=0.71$; and stages of assessment, $F(2,258)=138.20$; $p<.001 ;$ eta squared $=0.35$. Means and standard deviations for the six conditions are presented in Table 4. In this case, those who participated in the three stages were considered: 67 patients were excluded, as previously mentioned.

The means are also presented in Figure 1. The levels of distress significantly decreased among the stages. Apparently, the women's levels of distress decreased more strongly than that of men, though interaction between these variables was not observed. Additionally, the levels of distress reported by female patients remained significantly higher than those reported by male patients.

\section{Discussion}

A larger number of female patients initiated chemotherapy, showing the predominance of females among the public cared for by the facility where the study was 
Table 2

Percentage of Occurrence of Problems According to Gender $(N=328)$

\begin{tabular}{|c|c|c|c|c|c|c|}
\hline \multirow{2}{*}{ Problems } & \multicolumn{3}{|c|}{ Male } & \multicolumn{3}{|c|}{ Female } \\
\hline & Beginning & Middle & End & Beginning & Middle & End \\
\hline Practical problems & 49.5 & 40.5 & 46.8 & 58.6 & 43.7 & 37.3 \\
\hline Child care & 0.9 & 0 & 0 & 1 & 0.6 & 1.4 \\
\hline Housing & 9.2 & 8.3 & 3.1 & 20.1 & 13.2 & 9.8 \\
\hline Insurance/financial & 28.4 & 30.9 & 31.2 & 41.3 & 28.9 & 27.5 \\
\hline Transportation & 7.3 & 2.4 & 3.1 & 15.7 & 11.3 & 4.9 \\
\hline Work/school & 23.8 & 16.7 & 18.7 & 18.8 & 13.2 & 11.2 \\
\hline Family problems & 44 & 27.4 & 28.1 & 55.5 & 40.6 & 39.4 \\
\hline Dealing with children & 31.2 & 21.4 & 23.4 & 44 & 30.8 & 29.6 \\
\hline Dealing with partner & 22 & 11.9 & 9.3 & 23.6 & 16.3 & 16.2 \\
\hline Emotional problems & 88.1 & 65.5 & 71.8 & 97.9 & 81.2 & 73.9 \\
\hline Depression & 43.1 & 19 & 12.5 & 54.9 & 39 & 31.7 \\
\hline Fears & 37.6 & 11.9 & 15.6 & 63.9 & 30.2 & 33.8 \\
\hline Nervousness & 61.5 & 42.8 & 40.6 & 67.5 & 48.4 & 42.9 \\
\hline Sadness & 56.8 & 35.7 & 32.8 & 78.5 & 55.3 & 53.5 \\
\hline Worry & 68.8 & 45.2 & 53.1 & 82.7 & 64.7 & 63.4 \\
\hline Loss of interest in usual activities & 34.9 & 20.2 & 23.4 & 36.1 & 30.2 & 26.7 \\
\hline Spiritual problems & 7.3 & 1.2 & 3.1 & 7.8 & 6.8 & 3.5 \\
\hline Physical problems & 90.8 & 89.3 & 84.3 & 97.9 & 95.6 & 93.6 \\
\hline Appearance & 32.1 & 28.6 & 35.9 & 51.3 & 69.8 & 52.8 \\
\hline Bathing/dressing & 10.1 & 4.7 & 1.5 & 9.4 & 8.2 & 3.5 \\
\hline Breathing & 15.6 & 7.1 & 10.9 & 28.8 & 13.8 & 15.5 \\
\hline Changes in urination & 13.8 & 8.3 & 7.8 & 9.4 & 5.6 & 2.8 \\
\hline Constipation & 22 & 13.1 & 12.5 & 31.4 & 27.7 & 17.6 \\
\hline Diarrhea & 10.1 & 10.7 & 9.4 & 10.5 & 13.8 & 12.7 \\
\hline Eating & 36.7 & 29.7 & 31.2 & 35.6 & 24.5 & 23.2 \\
\hline Fatigue & 38.5 & 35.7 & 29.7 & 42.4 & 42.1 & 35.2 \\
\hline Feeling swollen & 13.8 & 17.8 & 21.9 & 24.6 & 35.2 & 29.6 \\
\hline Fever & 8.2 & 4.7 & 4.7 & 6.3 & 1.8 & 2.8 \\
\hline Getting around & 22 & 20.2 & 18.7 & 30.9 & 24.5 & 17.6 \\
\hline Indigestion & 5.5 & 4.7 & 0 & 7.8 & 5.6 & 1.4 \\
\hline Memory/concentration & 29.3 & 25 & 26.6 & 64.4 & 41.5 & 37.3 \\
\hline Mouth sores & 4.6 & 9.5 & 7.8 & 7.8 & 20.1 & 9.8 \\
\hline Nausea & 18.3 & 20.2 & 23.4 & 29.3 & 35.2 & 26.1 \\
\hline Nose dry/congested & 14.7 & 15.5 & 10.9 & 23 & 26.4 & 19.7 \\
\hline Pain & 41.3 & 28.6 & 17.2 & 40.8 & 24.5 & 26.8 \\
\hline Sexual & 25.7 & 19 & 23.4 & 28.3 & 22 & 22.5 \\
\hline Skin dry/itch & 30.3 & 22.6 & 23.4 & 37.7 & 44 & 34.5 \\
\hline Sleep & 50.4 & 42.8 & 48.4 & 59.7 & 51.6 & 48.6 \\
\hline Tingling in hands/feet & 18.3 & 23.8 & 31.2 & 16.2 & 21.4 & 22.5 \\
\hline
\end{tabular}

conducted. This fact cannot be explained by epidemiological data since, according to the National Institute of Cancer (Ministério da Saúde, 2011), men are more frequently diagnosed with cancer than women. It may, however, suggest that women use health services more frequently than men, as other studies have already reported (Doyal, 2001; Gomes, 2003; Macintyre et al., 1999; Macintyre, Hunt, \& Sweeting, 1996; Mast et al., 2010; Verbrugge, 1989).

In regard to health conditions and mortality, a higher incidence of men diagnosed in advanced stages (III and IV) of cancer was observed. Additionally, in terms of sample loss, a higher incidence of deaths was observed in the male group, which is also in agreement with previous studies
(Costa-Júnior \& Maia, 2009; Figueiredo, 2005; Gomes et al., 2007; Pinheiro et al., 2002; Rabasquinho \& Pereira, 2007).

The higher incidence of distress in the female group confirms previous studies (Admiraal et al., 2013; Akechi et al., 1998; Baider et al., 1997; Dunn et al., 2013; Giese-Davis et al., 2012; Hagedoorn et al., 2000; Hamama-Raz, 2012). We assumed that the higher number of items selected by women from the List of Problems reflected a greater facility of women to express and communicate physical, emotional and social problems, a fact already emphasized in the literature (Hagedoorn, Sanderman, Buunk, \& Woobes, 2002; Loscalzo et al., 2010). That is, women tend not to minimize their physical or emotional problems and seem to assume proactive behavior. 
Table 3

Logistic Regression of Patients' Genders on the List of Problems Reported at the Beginning, Middle and End of Treatment ( $N=328)$

\begin{tabular}{|c|c|c|c|c|}
\hline \multirow{2}{*}{ Variables } & \multirow{2}{*}{$\mathrm{B}(S D)$} & \multirow{2}{*}{ Odds Ratio } & \multicolumn{2}{|c|}{ 95\% Confidence Interval } \\
\hline & & & Low & High \\
\hline \multicolumn{5}{|l|}{ Beginning } \\
\hline Fear & $0.95(0.25)$ & 2.59 & 1.58 & 4.26 \\
\hline Appearance & $0.63(0.26)$ & 1.88 & 1.12 & 3.14 \\
\hline Changes in urination & $-0.83(0.40)$ & 0.43 & 0.19 & 0.95 \\
\hline Feeling swollen & $0.76(0.34)$ & 2.14 & 1.09 & 4.20 \\
\hline Memory/concentration & $0.76(0.26)$ & 2.14 & 1.28 & 3.57 \\
\hline \multicolumn{5}{|l|}{ Middle } \\
\hline Work & $-1.14(0.44)$ & 0.32 & 0.13 & 0.76 \\
\hline Worry & $1.28(0.32)$ & 3.61 & 1.94 & 6.74 \\
\hline Appearance & $0.93(0.30)$ & 2.54 & 1.40 & 4.58 \\
\hline Changes in urination & $-1.29(0.59)$ & 0.27 & 0.08 & 0.88 \\
\hline Constipation & $0.73(0.37)$ & 2.07 & 0.99 & 4.33 \\
\hline Eating & $-1.24(0.36)$ & 0.28 & 0.14 & 0.58 \\
\hline Feeling swollen & $0.91(0.35)$ & 2.48 & 1.25 & 4.94 \\
\hline Nausea & $0.90(0.35)$ & 2.48 & 1.24 & 4.93 \\
\hline Pain & $-0.73(0.31)$ & 0.48 & 0.25 & 0.92 \\
\hline Skin dry/itch & $0.79(0.32)$ & 2.20 & 1.18 & 4.12 \\
\hline \multicolumn{5}{|l|}{ End } \\
\hline Work & $-0.98(0.47)$ & 0.37 & 0.15 & 0.93 \\
\hline Depression & $1.12(0.42)$ & 3.08 & 1.33 & 7.09 \\
\hline Fears & $1.31(0.41)$ & 3.72 & 1.67 & 8.29 \\
\hline Appearance & $0.67(0.30)$ & 1.96 & 1.08 & 3.55 \\
\hline Constipation & $0.97(0.43)$ & 2.63 & 1.12 & 6.14 \\
\hline Eating & $-0.96(0.36)$ & 0.38 & 0.19 & 0.77 \\
\hline
\end{tabular}

Still addressing differences in gender roles, it is worth noting that female patients reported more concern for their spouses and children than do male patients. They also reported more emotions and spiritual concerns, as did participants of previous studies (Costa-Júnior \& Maia, 2009; McCaughan et al., 2012; Mast et al., 2010).

In regard to physical symptoms, the items not related to chemotherapy's side effects draw attention. 'Sleep disturbance' (e.g. insomnia) reported by the male group in the

Table 4

Mean and Standard Deviation of Distress in Male and Female Patients Participating in the Three Stages of Treatment $(N=261)$

\begin{tabular}{lcc}
\hline \multirow{2}{*}{ Distress } & \multicolumn{2}{c}{ Gender } \\
\cline { 2 - 3 } & Male & Female \\
\hline Beginning & & \\
$\quad$ Mean & 3.91 & 4.67 \\
$\quad$ Standard Deviation & 2.51 & 2.47 \\
Middle & & \\
$\quad$ Mean & 2.4 & 2.89 \\
$\quad$ Standard Deviation & 1.48 & 1.8 \\
End & & \\
$\quad$ Mean & 2.07 & 2.27 \\
$\quad$ Standard Deviation & 1.27 & 1.49 \\
\hline
\end{tabular}

three evaluations suggest a coping strategy characterized by introspection and an attempt to mobilize internal resources to solve problems on their own. This response happens especially at the beginning of the treatment when the patient's body is not yet worn out by the chemotherapy's side effects, responding only to the physical symptoms of the disease and to the emotional impact of the diagnosis (Kiss \& Meryn, 2001; Krouse et al., 2009; LeMasters, Madhavan, Sambamoorthi, \& Kurian, 2013; Nicholas, 2000; Salander \& Hamberg, 2005).

The emphasis in the female group on 'appearance' confirms various studies addressing bodily changes caused by therapeutic interventions in oncology and also is in agreement with studies addressing gender roles (Boquiren et al., 2013; Fobair et al., 2006; Kiss \& Meryn, 2001; LeMasters et al., 2013). In regard to 'memory/concentration' problems, it is important to note that such problems may be related to stress and to treatment side effects or to menopause (which may be a consequence of chemotherapy or hormone therapy or may not be), since the literature reports this symptom among women in the age group presented by the sample (Fan et al., 2005).

The item 'work' had predictive value for the male gender, which shows the concerns triggered by interruption of occupation some times during the treatment and also reinforce the stereotype of the male gender, in which instrumentality predominate (López-Sáez et al., 2008; Poeschl et al., 2003). 


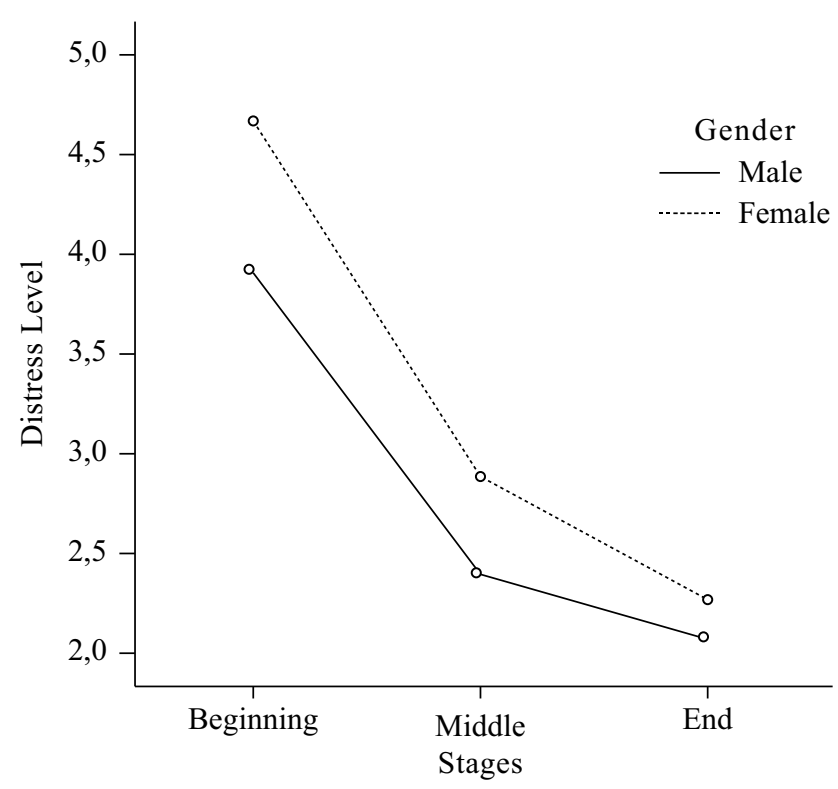

Figure 1. Mean of distress as a function of the gender of the patients participating in the beginning, middle and end of the chemotherapy $(N=261)$.

An increase in the number of physical problems was observed in the second assessment, which may reflect the side effects of the chemotherapy. At the last assessment, however, when the worn-out body still faces the adversities arising from treatment, fewer complaints were reported. This result may be associated with clinical management provided in the facility's routine and reinforces what has been shown in the literature; that is, without appropriate intervention, distress tends to remain high for at least six months after diagnosis (Akechi et al., 2006; Carlson, Waller, Groff, \& Bultz, 2013).

Concerning the sample's characterization, there was no predictive role between the studied categories (demographic data and characteristics of the disease) in the variable gender. This result, however, indicates that the differences found in terms of distress, the type and frequency of problems reported, are more related to gender than to the remaining sociodemographic characteristics (age, marital status, education) and to clinical aspects (type of cancer and staging).

In general, there was a significant effect for the variable 'gender' in the three stages of assessment, with a significant decrease over time. We suppose that such evidence indicates a gradual adaptation of patients to the cancer experience. As the quality of care provided in the studied facility may be a key factor for such developments, further studies with similar samples in different health services are needed for the purpose of comparison.

\section{Conclusion}

This study shows the relationship between gender and distress among patients with cancer over the course of chemotherapy. The importance of assessing distress in clinical monitoring is reaffirmed, providing support for the development of care routines that include goals of integral and humanized care.
We recommend further studies to differentiate distress among socio-economic and cultural segments in association with the variable 'gender'. The influence of the type of cancer also needs to be verified, since the sample was not representative in terms of other types of cancer, such as head and neck, genitourinary, melanoma, lungs and sarcoma. We also suggest that future studies address the influences of diverse chemotherapy protocols. Investigations with qualitative methodologies deserve attention because they will add to existing knowledge. All these efforts can contribute to satisfying the specific needs of men and women using Oncology services.

\section{References}

Admiraal, J. M., Reyners, A. K. L., \& Hoekstra-Weebers, J. E. H. M. (2013). Do cancer and treatment type affect distress? Psycho-Oncology, 22(8), 1766-1773. doi:10.1002/pon.3211 Akechi, T., Kugaya, A., Okamura, R., Nishiwaki, Y., Yamawaki, S., \& Uchitomi, Y. (1998). Predictive factors for psychological distress in ambulatory lung cancer patients. Supportive Care in Cancer, 6(3), 281-286. doi:10.1007/s005200050167

Akechi, T., Okuyama, T., Akizuki, N., Azuma, H., Sagawa, R., Furukawa, T. A., \& Uchitomi, Y. (2006). Course of psychological distress and its predictors in advanced non-small cell lung cancer patients. Psycho-Oncology, 15(6), 463-473. doi:10.1002/pon.975

American Cancer Society. (2006). Cancer facts \& figures. Atlanta, GA: Author.

Baider, L., \& Bengel, J. (2001). Cancer and the spouse: Genderrelated diferences in dealing with health care and illness. Critical Reviews in Oncology/Hematology, 40(2), 115-123.

Baider, L., Perry, S., Sison, A., Holland, J., Uziely, B., \& DeNour, A. K. (1997). The role of psychological variables in a group of melanoma patients. An Israeli sample. Psychosomatics, 38(1), 45-53. doi:10.1016/S0033-3182(97)71503-2

Bernardes, S. F., Silva, S. A., Carvalho, H., Costa, M., \& Pereira, S. (2013). Is it a (fe)male pain? Portuguese nurses' and laypeople's gendered representations of common pains. European Journal of Pain. Advance online publication. doi:10.1002/j.1532-2149.2013.00387.x

Boquiren, V. M., Esplen, M. J., Wong, J., Toner, B., \& Warner, E. (2013). Exploring the influence of gender-role socialization and objectified body consciousness on body image disturbance in breast cancer survivors. Psycho-Oncology. Advance online publication. doi:10.1002/pon.3271

Carlson, L. E., Waller, A., Groff, S. L., \& Bultz, B. D. (2013). Screening for distress, the sixth vital sign, in lung cancer patients: effects on pain, fatigue, and common problems - secondary outcomes of a randomized controlled trial. Psycho-Oncology, 22(8), 1880-1888. doi:10.1002/pon.3223

Clark, K. L., Loscalzo, M., Trask, P. C., Zabora, J., \& Philip, E. J. (2010). Psychological distress in patients with pancreatic cancer - an understudied group. PsychoOncology, 19(12), 1313-1320. doi:10.1002/pon.1697 
Costa-Júnior, F. M., \& Maia, A. C. B. (2009). Concepções de homens hospitalizados sobre a relação entre gênero e saúde. Psicologia: Teoria e Pesquisa, 25(1), 55-63. doi:10.1590/S0102-37722009000100007

Decat, C. S., Araujo, T. C. C. F., \& Stiles, J. (2011). Distress levels in patients undergoing chemotherapy in Brazil. PsychoOncology, 20(10), 1130-1133. doi:10.1002/pon.1833

Decat, C. S., Laros, J. A., \& Araujo, T. C. C. F. (2009). Termômetro de distress: Validação de um instrumento breve para avaliação diagnóstica de pacientes oncológicos. Psico-USF, 14(3), 253-260. doi:10.1590/S1413-82712009000300002

Doyal, L. (2001). Sex, gender, and health: The need for a new approach. British Medical Journal, 323, 1061-1063. doi:10.1136/bmj.323.7320.1061

Dunn, J., Ng, S. K., Holland, J., Aitken, J., Youl, P., Baade, P. D., \& Chambers, S. K. (2013). Trajectories of psychological distress after colorectal cancer. PsychoOncology, 22(8), 1759-1765. doi:10.1002/pon.3210

Fan, H. G. M., Houédé-Tchen, N., Yi, Q. L., Chemerynsky, I., Downie, F. P., Sabate, K., \& Tannock, I. F. (2005). Fatigue, menopausal symptoms, and cognitive function in women after adjuvant chemotherapy for breast cancer: 1- and 2 year follow-up of a prospective controlled study. Journal of Clinical Oncology, 23(31), 8025-8032. doi:10.1200/JCO.2005.01.6550

Fávero, M. H. (2010). Psicologia do gênero: Psicobiografia, sociocultura e transformações. Curitiba, PR: Editora UFPR.

Fife, B. L., Kennedy, V. N., \& Robinson, L. (1994). Gender and adjustment to cancer: Clinical implications. Journal of Psychosocial Oncology, 12(1-2), 1-21. doi:10.1300/J077V12N01_01

Figueiredo, W. (2005). Assistência à saúde dos homens: Um desafio para os serviços de atenção primária. Ciência \& Saúde Coletiva, 10(1), 105-109. doi:10.1590/S1413-81232005000100017

Fobair, P., Stewart, S. L., Chang, S., D’Onofrio, C., Banks, P. J., \& Bloom, J. R. (2006). Body image and sexual problems in young women with breast cancer. PsychoOncology, 15(7), 579-594. doi:10.1002/pon.991

Giese-Davis, J., Waller, A., Carlson, L. E., Groff, S. L., Zhong, L., Neri, E.,... Bultz, B. (2012). Screening for distress, the 6th vital sign: Common problems in cancer outpatients over one year in usual care: Associations with marital status, sex, and age. BMC Cancer, 12, 441-452. doi:10.1186/1471-2407-12-441

Gomes, R. (2003). Sexualidade masculina e saúde do homem: Proposta para uma discussão. Ciência \& Saúde Coletiva, 8(3), 825-829. doi:10.1590/S1413-81232003000300017

Gomes, R., Nascimento, E. F., \& Araújo, F. C. (2007). Por que os homens buscam menos os serviços de saúde do que as mulheres? As explicações de homens com baixa escolaridade e de homens com ensino superior. Cadernos de Saúde Pública, 23(3), 565-574. doi:10.1590/S0102-311X2007000300015
Good, G. E., \& Sherrod, N. B. (2001). The psychology of men and masculinity: Research status and future direction. In R. K. Unger (Ed.), Handbook of psychology of women and gender (pp. 201-213). Hoboken, NJ: John Wiley \& Sons.

Greimel, E. R., Padilla, G. V., \& Grant, M. M. (1998). Gender differences in outcomes among patients with cancer. Psycho-Oncology, 7, 197-207. doi:10.1002/(SICI)10991611(199805/06)7:3<197::AID-PON303>3.0.CO;2-Q

Hagedoorn, M., Buunk, B. P., Kuijer, R. G., Wobbes, T., \& Sanderman, R. (2000). Couples dealing with cancer: Role and gender differences regarding psychological distress and quality of life. Psycho-Oncology, 9(3), 232242. doi:10.1002/1099-1611(200005/06)9:3<232::AIDPON458>3.0.CO;2-J

Hagedoorn, M., Sanderman, R., Bolks, H. N., Tuinstra, J., \& Coyne, J. C. (2008). Distress in couples coping with cancer: A meta-analysis and critical review of role and gender effects. Psychological Bulletin, 134(1), 1-30. doi:10.1037/0033-2909.134.1.1

Hagedoorn, M., Sanderman, R., Buunk, B. P., \& Wobbes, T. (2002). Failing in spousal caregiving: The 'identityrelevant stress' hypothesis to explain sex differences in caregiver distress. British Journal of Health Psychology, 7(4), 481-494. doi:10.1348/135910702320645435

Hamama-Raz, H. (2012). Does psychological adjustment of melanoma survivors differ between genders? PsychoOncology, 21(3), 255-263. doi:10.1002/pon.1889

Holland, J. C., Andersen, B., Breitbart, W. S., Buchmann, L. O., Compas, B., Deshields, T. L., Freedman-Cass, D. A. (2013). Distress management. Journal of the National Comprehensive Cancer Network, 11(2), 190-209.

Holland, J. C., \& Bultz, B. D. (2007). The NCCN guideline for distress management: A case for making distress the sixth vital sign. Journal of the National Comprehensive Cancer Network, 5(1), 3-7.

Kiss, A., \& Meryn, S. (2001). Effect of sex and gender on psychosocial aspects of prostate and breast cancer. British Medical Journal, 323(7320), 1055-1058. doi:10.1136/bmj.323.7320.1055

Krouse, R. S., Herrinton, L. J., Grant, M., Wendel, C. S., Green, S. B., Mohler, M. J., Hornbrook, M. C. (2009). Health-related quality of life among long-term rectal cancer survivors with an ostomy: Manifestations by sex. Journal of Clinical Oncology, 27(28), 4664-4670. doi:10.1200/JCO.2008.20.9502

LeMasters, T., Madhavan, S., Sambamoorthi, U., \& Kurian, S. (2013). A population-based study comparing HRQoL among breast, prostate, and colorectal cancer survivors to propensity score matched controls, by cancer type, and gender. Psycho-Oncology, 22(10), 2270-2282. doi:10.1002/pon.3288

López-Sáez, M., Morales, J. F., \& Lisbona, A. (2008). Evolution of gender stereotypes in Spain: Traits and roles. Spanish Journal of Psychology, 11(2), 609-617. 
Loscalzo, M. J., Kim, Y., \& Clark, K. L. (2010). Gender and caregiving. In J. C. Holland, W. S. Breitbart, P. B. Jacobsen, M. S. Lederberg, M. J. Loscalzo, \& R. McCorkle (Eds.), Psycho-oncology (2nd ed., pp. 522-526). New York, NY: Oxford University Press.

Macintyre, S., Ford, G., \& Hunt, K. (1999). Do women "over-report" morbidity? Men's and women's responses to structured prompting on a standard question on long standing illness. Social Science \& Medicine, 48(1), 89-98. doi:10.1016/S0277-9536(98)00292-5

Macintyre, S., Hunt, K., \& Sweeting, H. (1996). Gender differences in health: Are things really as simple as they seem? Social Science \& Medicine, 42(4), 617-624. doi:10.1016/0277-9536(95)00335-5

Mast, M. S., Klöckner, C., \& Hall, J. A. (2010). Gender, power, and non-verbal communication. In D. W. Kissane, B. D. Bultz, P. N. Butow, \& I. G. Finlay (Eds.), Handbook of communication in oncology and palliative care (pp. 63-73). New York, NY: Oxford University Press.

McCaughan, E., Prue, G., Parahoo, K., Mcllfatrick, S., \& McKenna, H. (2012). Exploring and comparing the experience and coping behaviour of men and women with colorectal cancer after chemotherapy treatment: A qualitative longitudinal study. Psycho-Oncology, 21(1), 64-71. doi:10.1002/pon.1871

Ministério da Saúde. Instituto Nacional de Câncer José Alencar Gomes da Silva. (2011). Estimativa 2012: Incidência de câncer no Brasil. Rio de Janeiro, RJ: INCA.

National Comprehensive Cancer Network. (2007). Distress management. Clinical practice guidelines in Oncology. Fort Washington, PA: American Cancer Society and National Comprehensive Cancer Network.

Nicholas, D. R. (2000). Men, masculinity, and cancer: Risk factor behaviors, early detection, and psychosocial adaptation. Journal of American College Health, 49(1), 27-33. doi:10.1080/07448480009596279

Pinheiro, R. S., Viacava, F., Travassos, C., \& Brito, A. S. (2002). Gênero, morbidade, acesso e utilização de serviços de saúde no Brasil. Ciência \& Saúde Coletiva, 7(4), 687-707. doi:10.1590/S1413-81232002000400007

Poeschl, G., Múrias, C., \& Ribeiro, R. (2003). As diferenças entre os sexos: Mito ou realidade? Análise Psicológica, 21(2), 213-228.

Rabasquinho, C., \& Pereira, H. (2007). Género e saúde mental: Uma abordagem epidemiológica. Análise Psicológica, 25(3), 439-454.

Rezende, V. L., Derchain, S., Botega, N. J., Sarian, L. O., Vial, D. L., Morais, S. S., \& Perdicaris, A. A. M. (2010). Avaliação psicológica dos cuidadores de mulheres com câncer pelo General Comfort Questionnaire. Paidéia (Ribeirão Preto), 20(46),229-237.doi:10.1590/S0103-863X20100002000010

Rogers, W. S., \& Rogers, R. S. (2001). The psychology of gender and sexuality: An introduction. Buckingham, England: Open University Press.
Salander, P., \& Hamberg, K. (2005). Gender differences in patients'writtennarratives aboutbeing diagnosed with cancer. Psycho-Oncology, 14(8), 684-695. doi:10.1002/pon.895

Silva, M. R. M. S., Mendonça, H., \& Zanini, D. S. (2010). Diferenças de gênero e valores relativos ao trabalho. Paidéia (Ribeirão Preto), 20(45), 39-45. doi:10.1590/S0103-863X2010000100006

Snooks, M. K. (2009). Health psychology: Biological, psychological, and sociocultural perspectives. Boston, MA: Jones and Bartlett.

Steensma, T. D., Kreukels, B. P. C., de Vries, A. L., \& CohenKettenis, P. T. (2013). Gender identity development in adolescence. Hormone and Behavior, 64(2), 288-297. doi:10.1016/j.yhbeh.2013.02.020

Toner, B., Tang, T., Ali, A., Akman, D., Stuckless, N., Esplen, M. J.,... Ross, L. (2012). Developing a gender role socialization scale. In J. L. Oliffe, \& L. Graves (Eds.), Designing and conducting gender, sex \& health research (pp. 189-200). Thousand Oaks, CA: SAGE. doi:10.4135/9781452230610

Verbrugge, L. M. (1989). The Twain meet: Empirical explanations of sex differences in health and mortality. Journal of Health and Social Behavior, 30, 282-304.

Cristiane Decat Bergerot holds a Ph.D. from the Graduate Program in Human Development and Health Processes of the Universidade de Brasília.

Tereza Cristina Cavalcanti Ferreira de Araujo is an Associate Professor of the Psychology Institute of the Universidade de Brasília.

Bartholomeu Tôrres Tróccoli is an Associate Professor of the Psychology Institute of the Universidade de Brasília.

Received: Nov. $15^{\text {th }}, 2012$ $1^{s t}$ Revision: Oct. 23 ${ }^{\text {rd }}, 2013$ Approved: Jan. $7^{\text {th }}, 2014$

How to cite this article:

Bergerot, C. D., Araujo, T. C. C. F., \& Tróccoli, B. T. (2014). Assessment of distress among chemotherapy patients: A comparative study of gender. Paidéia (Ribeirão Preto), 24(57), 57-65. doi:10.1590/1982-43272457201408 


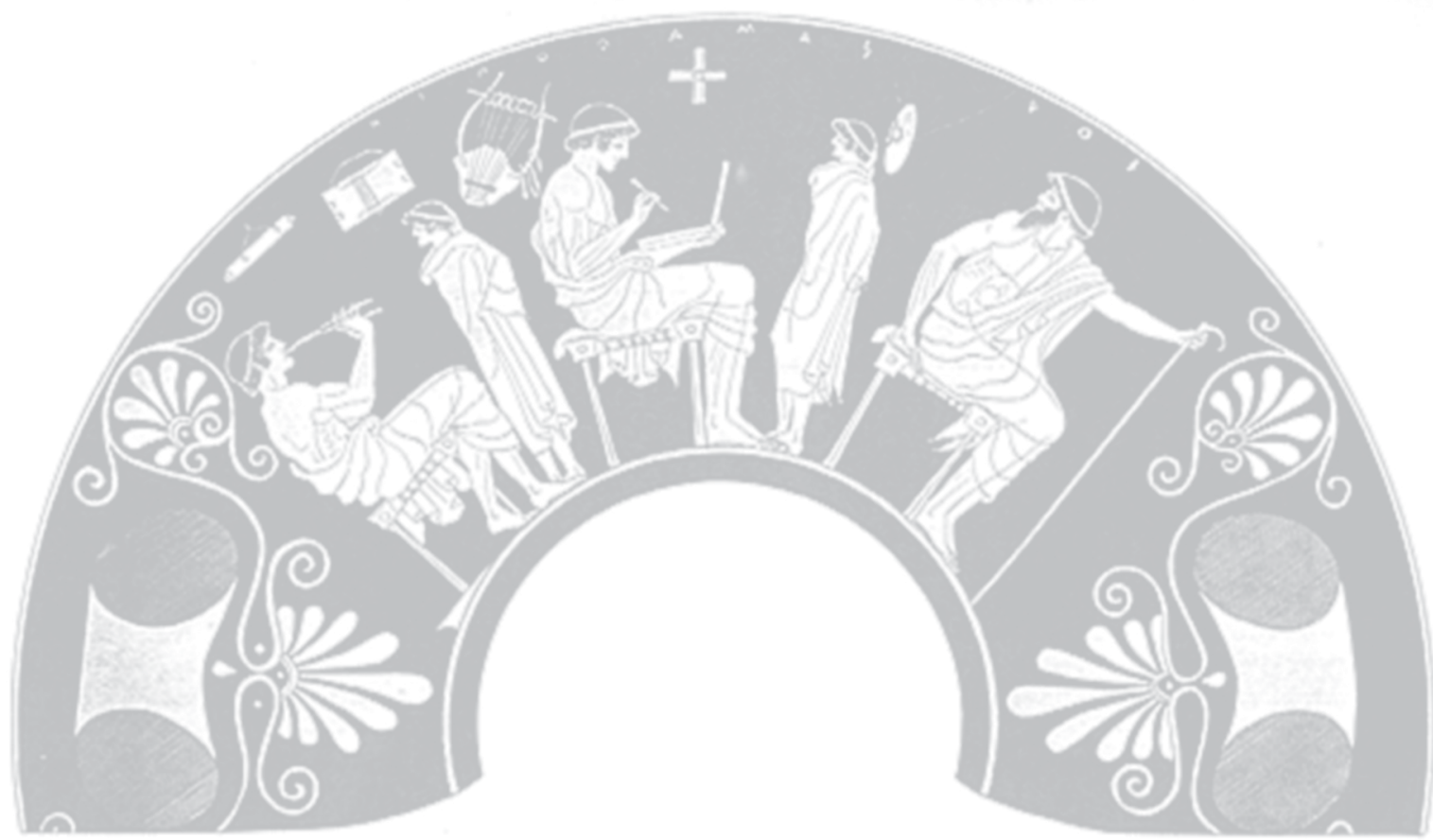

